\title{
INSTALMENT SELLING: THE RELATION BETWEEN ITS DEVELOPMENT IN MODERN BUSINESS AND THE LAW
}

\author{
NATHAN IsAacs*
}

Instead of asking, as many do, why instalment selling has come to be characteristic of the retail business in many lines today, perhaps we shall do well to invert the question and ask why the extensive development of such a practice has been postponed in business history to the current generation. Every element in the machine is old; perhaps it would be hard to discover novelty in the combination. The sale of goods to consumers on credit is as old as the tally sticks of the mediaeval innkeeper, or older. The arrangement that a debt shall fall due in a series of payments long antedates such fantastic names as "easy payments" or "budget plan"-its use for the purchase of houses antedates legal memory. The security phase, particularly the idea of making a hold on the thing sold the basis of safety, is obviously suggested by the analogy of real estate transactions. The early beginnings of a combination of these ideas in the sale of chattels is an obscure and yet inviting problem in business history. But at least we may venture the statement that the whole plan was invented and in use in limited fields more than a half century before its modern expansion began. In the middle of, the Igth century, furniture, pianos, sewing machines, and books were sold under well-developed instalment plans. Why, then, the delay in the introduction of this tempting mode of overcoming sales resistance and of anticipating future earnings, from the seller's point of view, and of enjoying the thing purchased while paying for it, from the point of view of the buyer?

At first sight it may seem that the explanation is to be sought in the state of the law. Parallel attempts have been made to relate the whole evolution of credit to legal history. But such efforts have generally revealed two startling discrepancies: first, that where credit devices are wanted and the law fails to grant them, human ingenuity has frequently worked out pseudo-legal or extra-legal sanctions for them; secondly, that when such devices are not wanted they lie unused in the law for centuries after they are provided. To illustrate the first discrepancy, we have only to turn to the early law of pledges and liens, which in most countries came into

-A.B., 1907, University of Cincinnati; A.M., 1908, Ph.D., LL.B., 1910, S.J.D., 1920, Harvard. Professor of Business Law in the Harvard School of Business Administration. Author of The Law in Business Problems and contributor to legal and other periodicals. 
existence independently of enforceable contracts. To illustrate the latter, we have only to recall that the legal foundations for our credit system were complete in the early 1600 's, when the understanding that "every contract executory imports in itself an assumpsit," provided a simple action for the collection of debts of all kinds in the ordinary courts. But it would be vain to look for anything like the modern credit system in 17th century or even 18 th century business. What we are concerned with here is only a specific application of this generalization. The legal instrumentalities that have been found useful in the development of instalment selling are not new.

We must therefore find the explanation of the delayed development of instalment selling in economic, social and psychological terms largely outside of the law. Some of these elements are obvious, but others are too subtle for statement, too hazy to be photographed, too slight to be ponderable.

Economists and other specialists have given much attention to the study of these aspects of instalment plans, though they have usually approached the matter from the other end-the easy end of explaining why there has been a recent development. I shall not attempt to give new answers here, but merely to recast some of the questions-in deference, if you wish, to the success of their demonstrations.

(I) Why didn't the manufacturers of carriages and the manufacturers of the first automobiles, or the predecessors of the manufacturers of the various gadgets that fill modern commerce, resort to the obvious method of selling on time? (2) Again, a second question may be considered together with the first: What other methods or substitutes were available to accomplish the same business and social ends as have been accomplished since the World War by instalment selling, and why have these failed to continue to solve the difficulty?

Any answer to these questions involves a consideration of some of the following elements: (a) the types of purchaser; (b) the types of article; (c) the conditions of competition and the practices of trades; (d) popular prejudices; (e) the presence or absence of facilitating institutions; (f) the legal environment or setting. A word as to each of these elements, though they do not make up a logical list in that they are neither exhaustive nor mutually exclusive, will reveal the part played by the law both directly and indirectly in the changes that have already come about, and may throw some light on the future.

(a) We might dismiss the discussion of types of purchaser with the remark that as an incident to a higher standard of living or a more extravagant mode of living, more people of small means buy cars than ever thought of buying horses and carriages. Not only do the newer buyers need more credit, but they have less personal basis on which to ask for it. The resulting tendency is obvious. We should also bear in mind, however, the transition from the simple system of a maker selling to a consumer from his neighborhood, to that in which the national manufacturer passes goods through the hands of the middleman whose sole job is to sell. The 
credit experience of a tailor who makes clothes to order for his clientele is quite different from that of the seller of ready-made clothing. The former reflects the general conditions of a century ago; the latter, the prevailing marketing conditions of today. It is hard to conceive just how instalment selling can be grafted on the former or that it would be at all desirable. The plan has found its place in the less personal touch-and-go relation of the latter system, even for commodities as ill-fitted to it in most respects as clothing.

(b) As to the types of articles: obviously there must be a second-hand market, otherwise there is no basis for security in them. It must, furthermore, be an established second-hand market, and not merely a disordered junk market. Goods lending themselves to reconditioning fit this purpose most readily. Such goods also have a trade-in value. In the igth century the best examples were sewing machines and pianos. Today the automobile takes first rank. Household furniture, radios, and electrical equipment rank lower in this respect. But conditions change. It is not long since a "second-hand" automobile-the term has of course been displaced on the market by the more euphonious "used car" or "traded-in-car"-was wisely shunned except by the amateur mechanic. But standardization of parts and repairs, improvement in the cars themselves, the recognized habits of the trade, and, chiefly, reasonably satisfactory experience, have broken down much of this resistance and simultaneously built up the basis of automobile financing. Without such a basis, trade-in values are fictitious and financing is a sham in which prices must be set so high that the "down payment" is looked to to cover costs. If there are more articles in the market today than formerly to which the instalment plan is applicable, the reason is to be sought partly in the state of the corresponding second-hand markets, partly in the increase of sturdy, substantial, or reconditionable goods, and partly in the skill with which repossessed goods are handled. One other aspect of the goods may be mentioned here: some goods are more readily identifiable than others. Numbered engines or works and similarly identified articles lend themselves better to the protection devices than pieces of furniture that are as much alike as peas in a pod-a characteristic situation under mass production. Again, bulky objects like pianos present fewer difficulties than easily moved goods, particularly automobiles. These differences entail practical difficulties when we come to the application of legal machinery; they are not, however, insuperable. One other type of commodity lends itself to financing: fixtures that become a part of the realty. Of these we shall have a word to say in discussing legal machinery.

(c) Perhaps the simplest answer to our questions about the pre-instalment period is that business had not yet been driven to the instalment system. Intensity of competition was, of course, a factor in the development of automobile financing. The system operates as a high power method of selling electric refrigerators, furnaces, cash registers, farm machinery, and other expensive durable equipment. It is interesting to run through the N. R. A. codes of fair competition and note allusions there 
to liberal credit terms as unfair, and yet to find "financing" so well established in certain industries that it is accepted in them as normal.

(d) Popular prejudice' had to be overcome before instalment businesses could reach their present state. To this end the sellers and others interested resorted to petty advertising and sales tactics. They invented fancy names for their plans. They drew up forms that were at once impressive and innocuous-looking. They avoided publicity as much as possible. But they also had to use common sense. The rates of interest, no matter how artfully concealed, could not go beyond certain limits. Nor could a business be built on the practice of continuing to collect instalments after an article had worn out. Theoretically, the seller looking to the thing for security could deal with all persons alike; practically, of course, he could not. With some people he obviously ran such risks as rapid deterioration, destruction, concealment, or removal of the goods, unpleasant publicity in the process of enforcement of claims, or even the confiscation for misuse of such articles as automobiles transporting liquor under prohibition. Of course, consumer credit is based more on the probable willingness and ability to pay than upon amenability to legal compulsion. Hence, the problem of introducing the instalment plan or using it in any given business always had its personal side, which, though not appearing on paper or reflected in the legal set-up, sometimes spelled the difference between success and failure.

Of course the thrift habits of a community have a bearing on the social standing of the borrower. Education exerts an influence. In some types of communities, sharp distinctions are made between borrowing for consumption and borrowing for production. There are, indeed, borrower communities and lender communities in the country, each of which is equipped with its own mores. An important factor is the question of likelihood of being able to repay. But there are other factors: there are stages of community development in which saving has a tremendous social importance; there are perhaps others in which the encouragement of spending is necessary. In any event, whether wisely or not, Americans whose grandfathers regarded all luxuries askance and luxuries bought on credit as sinful, have no difficulty in persuading themselves that they are really engaging in wise compulsory saving when they buy such useful articles as electric washing machines, electric refrigerators, and, of course, automobiles; on the instalment plan. Didn't their grandfathers buy houses that way?

(e) In course of time the practices referred to became institutionalized. I use this term in the sense of being facilitated by specially devised and more or less standardized practices, forms, organizations. There is a vast difference between the puzzling course of two men planning an instalment sale between themselves, say in the transfer of a collection of books or a stock in trade, and the smooth path of signing the neatly prepared forms at the deferred-payment-plan window of an automobile salesroom. Standardization of practices operates here in several ways. It not only saves time and effort, but avoids embarrassment and the appearance of 
asking for a favor; it destroys fear and sales resistance because of the reasonable assumption that the treatment accorded all comers alike has been fought out and tested and that it is on the whole tolerable. Of course abuses may be standardized, too, and agreements one-sided as to rates, risk bearing, waivers, and modes of enforcement may be drawn, but as a practice becomes established and its corners rubbed down by competition, this danger does decrease. But institutionalizing goes further than forms. It includes the development of other facilities, such as credit agencies for the investigation of consumer-purchasers and other systems for the exchange of information. It includes special departments or subsidiaries or separate companies organized to take care of this kind of business. It includes the training of specialists or the making of routine connections to handle every stage of the work down to repossession, reconditioning, and resale of the commodity sold. A part-a large part, perhaps - of the standardizing or institutionalizing falls to the lawyer.

(f) We have already said that the principal facilities furnished by the law for the instalment system were old when first thought of in connection with such a purpose. This fact might at first glance suggest that there was little for the lawyers to do but apply them. There is, however, another side to the story. Just because the devices had come into existence and had been crystallized with no thought of serving the modern objective, they were in a measure ill-suited to it and called for careful adaptation rather than simple adoption. This process has been accomplished in part by draftsmanship, in part by legislation, and in part by cutting the business according to the cloth provided by law.

Let us consider the credit security devices that were available. Of the two great divisions, personal security and real security, personal security in the sense of guaranty, suretyship, third party endorsement, and the like, has been ruled out because of its inconvenience and uncertainty. A distinction might be drawn between xgth century rural conditions and 2oth century urban or quasi-urban conditions in America in this regard. In the former, the practice of acting as surety for a neighbor or relative or dependent less known in the community, or even vouching for him less formally, played a conspicuous part. In the latter situation, the large scale dealer knows no more about my neighbor's word than he does about mine. The relation becomes impersonalized, and the reliance on things rather than on persons for additional security is inevitable. Of the real security that is left us, we must avoid possessory holds, such as possessory liens and pledges, because while serving their security purpose they defeat the primary business purpose of the transaction by withholding the goods from use. There remain, therefore, what might be called title holds, such as those involved in chattel mortgages, conditional sales, leases, or other bailment arrangements with privilege of purchase, or trust receipts. Some of these are obviously too heavy for ordinary use. Thus, the idea of giving commodities to a trustee who issues certificates to those who furnish the money, and then renting to the user under an elaborate lease that takes care of principal and interest, 
may serve for a railway's rolling stock but it just won't do for ordinary consumer credit. Hence, we are practically limited to the chattel mortgage, the conditional sale, and some form of "hire purchase" or leasing. ${ }^{1}$ To make these safe for the creditor, lawyers have multiplied clauses adding to the scope of self-help on the part of the creditor, imposing waivers of exemptions and other rights and warrants to confess judgments on the buyer and passing every conceivable risk and expense on to him. On the other hand, laws have been enacted to make such clauses fairer from the buyer's point of view, and more reasonable from that of the general public. Among these laws, are, of course, usury laws, which sometimes need particular pointing to take care of interest hidden under the guise of fees, laws imposing formalities or at least publicity on the mode of foreclosure, laws limiting the amount of "rental" or 'other sums, however named in the documents, which are in reality forfeitures, and, in general, laws tending to standardize the terms of such agreements on an equitable basis. To protect the interest of the public, or at least to define its interest when that collides with the interest of the lien holder, the law provides in general for registration, filing, or otherwise destroying the secrecy of the lien as a condition precedent to holding it against the bona fide purchaser for value or, in some statutes, other claimants less clearly entitled to such protection. In the stage through which we are passing, there is a lack of uniformity, but no doubt as to the direction of progress. The Uniform Conditional Sales Act has been adopted in only nine states; the Uniform Trust Receipt Act in only one; the Uniform Chattel Mortgage Act in four. There is, furthermore, great diversity of opinion as to whether particular legislation on secret liens-and registration applies to slightly different forms, such as the leases of the hire-purchase arrangement. And the difficulties and diversities become almost hopeless when we inject into the puzzle picture the possibility that the chattel sold may become a part of the realty. The question whether separate real estate and chattel records are desirable or effective without actual consents from owners or mortgagees of the real estate, must be resolved in the present state of the law individually for each state and almost for each type of fixture.

Besides resolving doubts of this kind, the future tasks of the law regarding instalment sales point in two directions: to perfect the machinery of legitimate instalment selling; and to check abuises.

The imperfection attracting most attention at present is the absence of a national registration system for automobiles. It was quite natural to have land titles and incumbrances registered locally in the county court house or some other convenient building. It was at first quite reasonable to copy this provision into the registration or filing of documents pertaining to movables. It was soon found necessary, however, to supplement such legislation by making it illegal to remove goods from the place of such registry without proper notices and consents. Nevertheless, cases did arise in which pianos and such bulky goods were removed and sold in other states to

${ }^{1}$ For a discussion of these security devices, see Adelson, The Mechanics of the Instalment Credit Sale, infra, at p. 227. 
innocent purchasers. Holdings in favor of the mortgagee in such cases still left the buyer without any genuine means of looking up the title to goods offered him. $\mathrm{He}$ was thrown back on the common law risk. But when the automobile became the chief commodity dealt with in this way, the absence of a nation-wide record became serious indeed. The registries of motor vehicles in several states are armed with power to inquire into the history of a car as a condition precedent to issuing a license. This is a step in a direction in which we may expect legislatures to go further. ${ }^{2}$ Other demands on the part of those who would make instalment machinery more effective go to the facilitating of recaption, to the punishment of various types of fraud or unfairness on the part of persons obtaining credit, and to the recognition of instalment financing and instalment paper in the banking world.

More attention, however, is directed towards the removal of abuses from the borrower's point of view. Besides developing such legislation as that already listed as showing the type of transition through which we are passing, we may expect the weeding out of procedural abuses, and the further adjustment of charges to a fair interest plus reasonable costs. ${ }^{3}$ Whether legislation should at the present stage go further to stimulate, direct or check instalment buying is, of course, controversial in the highest degree. Depression studies run all the way from attempts to attribute the severity of the depression to unwise instalment buying and selling, to triumphant demonstrations that instalment selling has stood the test of depressions. What must be borne in mind, however, as we look forward to the future with legislative action or even self-regulation by trades in view, is that there is a difference between the sudden expansion of a practice without legal control, such as we witnessed in the I920's, and its continued use in industries where it succeeds in establishing itself, with abuses pretty well checked-the condition we may look for immediately ahead.

\footnotetext{
${ }^{2}$ For a discussion of proposals for legislation in this field, see Myerson, Practical Aspects of Some Legal Problems of Sales Finance Companies, infra, at p. 250.

sor a discussion of proposals for legislation affecting rates, see Foster and Foster, Rate Aspects of Instalment Legislation, infra, p. I89.
} 